\title{
Staphylococcus saprophyticus Recovered from Humans, Food, and Recreational Waters in Rio de Janeiro, Brazil
}

\author{
Viviane Santos de Sousa, ${ }_{1}^{1}$ Ana Paula de Souza da-Silva, ${ }^{1}$ Leif Sorenson, ${ }^{2}$ \\ Raphael Paiva Paschoal, ${ }^{1}$ Renata Fernandes Rabello, ${ }^{3}$ Eloiza Helena Campana, ${ }^{1}$ \\ Márcia Soares Pinheiro, ${ }^{3}$ Lyssa Oliveira Ferreira dos Santos, ${ }^{1}$ Natacha Martins, ${ }^{1}$ \\ Ana Carolina Nunes Botelho, ${ }^{1}$ Renata Cristina Picão, ${ }^{1}$ Sérgio Eduardo Longo Fracalanzza, ${ }^{1}$ \\ Lee Woodland Riley, ${ }^{2}$ George Sensabaugh, ${ }^{2}$ and Beatriz Meurer Moreira ${ }^{1}$ \\ ${ }^{1}$ Laboratório de Investigação em Microbiologia Médica, Universidade Federal do Rio de Janeiro, Rio de Janeiro, RJ, Brazil \\ ${ }^{2}$ School of Public Health, University of California, Berkeley, Berkeley, CA, USA \\ ${ }^{3}$ Instituto Biomédico, Universidade Federal Fluminense, Niterói, RJ, Brazil \\ Correspondence should be addressed to Beatriz Meurer Moreira; bmeurer@micro.ufrj.br
}

Received 23 February 2017; Accepted 19 April 2017; Published 24 May 2017

Academic Editor: Todd R. Callaway

Copyright (C) 2017 Viviane Santos de Sousa et al. This is an open access article distributed under the Creative Commons Attribution License, which permits unrestricted use, distribution, and reproduction in any medium, provided the original work is properly cited.

Staphylococcus saprophyticus is an important agent of urinary tract infection (UTI) in young women, but information about this pathogen in human microbiota and in common environment is lacking. The aim of this study was to characterize S. saprophyticus isolates from genitoanal microbiota of 621 pregnant women, 10 minas cheese packs, and five beaches in Rio de Janeiro city and compare PFGE profiles of these isolates with five UTI PFGE clusters described in this city. We investigated 65 S. saprophyticus isolates from microbiota, 13 from minas cheese, and 30 from beaches and 32 UTI isolates. Antimicrobial resistance was determined by disk diffusion, MIC by agar dilution, and PCR. Erythromycin-resistance genes $e r m(\mathrm{C}), m s r(\mathrm{~A}), m s r(\mathrm{~B}), m p h(\mathrm{C})$, and $\operatorname{lin}(\mathrm{A})$ were found in $93 \%$ of isolates. Trimethoprim-sulfamethoxazole resistance correlated with $d f r G$ or $d f r A$ genes. Three cefoxitin-resistant isolates carried the mecA gene. All isolates obtained from cheese were susceptible to all antimicrobial agents. Six of 10 pregnant women with $>1$ isolate had monoclonal colonization. Isolates from pregnant women shared $100 \%$ similarity with UTI PFGE cluster types A and E obtained almost 10 years previously, suggesting temporal persistence of S. saprophyticus. Antimicrobial resistance of beach isolates reflected the profiles of human isolates. Taken together, results indicate a shared source for human and environmental isolates.

\section{Introduction}

The source or reservoir of Staphylococcus saprophyticus for humans is not fully known. This coagulase-negative microorganism is recognized to cause urinary tract infection (UTI) in sexually active young women [1]. Despite the numerous reports of this microorganism in food [2-4], the relationship between these findings and the occurrence of UTI in humans has not been demonstrated [5]. In Brazil, S. saprophyticus was described in minas cheese [6], one of the most popular kinds of fresh cheese in the country, and in the water of a polluted river [7]. In addition, reports of S. saprophyticus in the marine environment $[8]$ and food derived from fish $[9,10]$ draw attention to the spread of this microorganism. These may indicate that nonhuman sources of $S$. saprophyticus colonization may include, in addition to food, contact with the marine environment, an unexplored phenomenon.

In a previous report, we described the distribution of pulsed-field gel electrophoresis (PFGE) types in a population of 32 S. saprophyticus isolates from community-acquired UTI in Rio de Janeiro from 2005 to 2006 [11]. Clusters of isolates with indistinguishable PFGE patterns were observed among unrelated individuals, indicating possible point sources of this uropathogen. Such putative sources were not investigated in the previous study, and much of the epidemiology of $S$. saprophyticus UTI is yet to be described. 


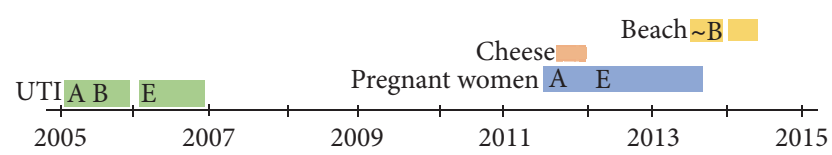

FIGURE 1: Distribution of isolates obtained from different sources in Rio de Janeiro according to time. Capital letters represent the urinary tract infection (UTI) PFGE types. “ B": beach isolate with $82 \%$ similarity with UTI type B.

The emergence of antimicrobial resistance in uropathogens is a worldwide concern. The characterization of resistance determinants in UTI pathogens is important for the clinical management of UTI. Although S. saprophyticus may carry many resistance genes, most studies include this organism in a coagulase-negative group or deal with low numbers of samples [12-17], and the resistance determinants in clinical isolates are rarely described. Reports of the presence in the urogenital microbiota associated with UTI by this microorganism date from the 1980s [18]; therefore, recent evidence of this colonization in the human microbiota is lacking.

The aim of the present study was to characterize antimicrobial resistance genes in S. saprophyticus isolates from UTI cases, the microbiota of pregnant women, and two potential colonization sources: artisanal minas cheese and the waters of five beaches in the city of Rio de Janeiro. In addition, we aimed to compare the PFGE band profiles of these isolates with five uropathogenic S. saprophyticus clusters previously described in this city [11].

\section{Materials and Methods}

2.1. Bacterial Isolation and Identification. We obtained isolates from four sources: UTI [11], pregnant women's microbiota, minas cheese, and beach waters. We considered as suspect of S. saprophyticus the colonies from cultures of cheese and the microbiota samples that grew on Mannitol Salt Agar (BD, New Jersey, USA) with $100 \mu \mathrm{g} / \mathrm{mL}$ of novobiocin (Inlab, São Paulo, Brazil) and the colonies from beach water samples that grew on the same selective medium with addition of $0.005 \%$ sodium azide [28]. The distribution of isolates according to time (years) and source of detection is shown in Figure 1.

Isolates from UTI were obtained from 32 patients of two walk-in clinics in Rio de Janeiro city during March-November 2005 and March-November 2006 [11]. PFGE typing revealed the presence of five time-based clusters (types A-E) in isolates of patients coming from places spread in the community. One isolate of each cluster type was used in comparisons with PFGE types obtained in the present study. Isolates from pregnant women's microbiota were obtained from vaginal and anal swab specimens stored during surveillance for Streptococcus agalactiae colonization. Samples were collected from 621 healthy pregnant women in the 35-37th weeks of gestation, from August/2011 to August/2013; five colonies from vaginal and anal sites of each patient were selected for S. saprophyticus screening. Ten minas cheese packs from three different brands were obtained in November
2011 from different stores in eight neighborhoods in Rio de Janeiro city, taken to the lab in original packaging, and coded with roman numbers. Analysis was performed in $25 \mathrm{~g}$ samples from each cheese pack as described [29]. After dilutions, the material was seeded in Baird-Parker Agar (BD, New Jersey, USA); up to five colonies of each morphology were selected, isolated, and preserved. In this first step, we obtained 75 colonies from the ten cheese packs. In a second step, colonies were seeded onto S. saprophyticus selective medium.

Water samples were obtained in two time points, December 2013 and March 2014 (single-day collection each), from beaches of Botafogo, Copacabana, Flamengo, Ipanema, and Leblon, in Rio de Janeiro city. Water was collected in collaboration with previous study [30] with modifications in the process of obtaining isolates. Briefly, in the first sampling section, water volumes inoculated in each Petri dish were $200 \mu \mathrm{L}$ without filtering and $10 \mathrm{~mL}, 20 \mathrm{~mL}, 50 \mathrm{~mL}$, and $100 \mathrm{~mL}$ filtered in $0.22 \mu \mathrm{m}$ Millipore membranes (Merck, Darmstadt, Germany). In the second sampling section, after observing the high numbers of $S$. saprophyticus isolates obtained only from Leblon beach in the first section, only waters from this beach were sown in the five Petri dishes with different inoculum volumes. Waters from the other four beaches required just the $50 \mathrm{~mL}$ membrane filtration. Up to 16 colonies in each Petri dish were chosen and named according to the source and morphology.

All colonies were identified by biochemical tests [31] and matrix-assisted laser desorption ionization time of flight mass spectrometry (MALDI-TOF), using MALDI Biotyper 3.1 software (Bruker Daltonics) [32]. S. saprophyticus American Type Culture Collection (ATCC) 15305 was the control test. Isolates identified as S. saprophyticus were stored in suspensions containing $10 \%(\mathrm{w} / \mathrm{v})$ skimmed milk and $10 \%$ glycerol $(\mathrm{v} / \mathrm{v})$ in a freezer at $-20^{\circ} \mathrm{C}$.

2.2. Antimicrobial Susceptibility Test. The following antimicrobial agents (OXOID, Hampshire, England) were tested by disk diffusion method according to the Clinical and Laboratory Standards Institute (CLSI) $[33,34]$ : ciprofloxacin $(5 \mu \mathrm{g})$, clindamycin $(2 \mu \mathrm{g})$, erythromycin $(15 \mu \mathrm{g})$, gentamicin $(10 \mu \mathrm{g})$, levofloxacin $(5 \mu \mathrm{g})$, linezolid $(30 \mu \mathrm{g})$, nitrofurantoin $(300 \mu \mathrm{g})$, norfloxacin $(10 \mu \mathrm{g})$, penicillin (10 UI), and trimethoprimsulfamethoxazole $(1,25 / 23,75 \mu \mathrm{g})$. Cefoxitin $(30 \mu \mathrm{g})$ disks predicted oxacillin resistance. Clindamycin inducible resistance was determined by the disk diffusion $D$-test. For antimicrobials with any isolate showing resistance in disk diffusion tests, minimum inhibitory concentrations (MIC) $[33,34]$ were determined by agar dilution.

2.3. Detection of Antimicrobial Resistance Genes. Resistance determinants investigated and primers used in this study are described in Table 1. We screened for the presence of genes related to antimicrobial agents showing resistance in disk diffusion tests, including genes described in S. saprophyticus or other Staphylococcus species. We confirmed one PCR product of each gene by sequencing and comparisons in GenBank with BLAST. Sequencing was additionally performed for some of the UTI isolates to verify the presence 
TABLE 1: Primers used for screening of resistance determinants in Staphylococcus saprophyticus.

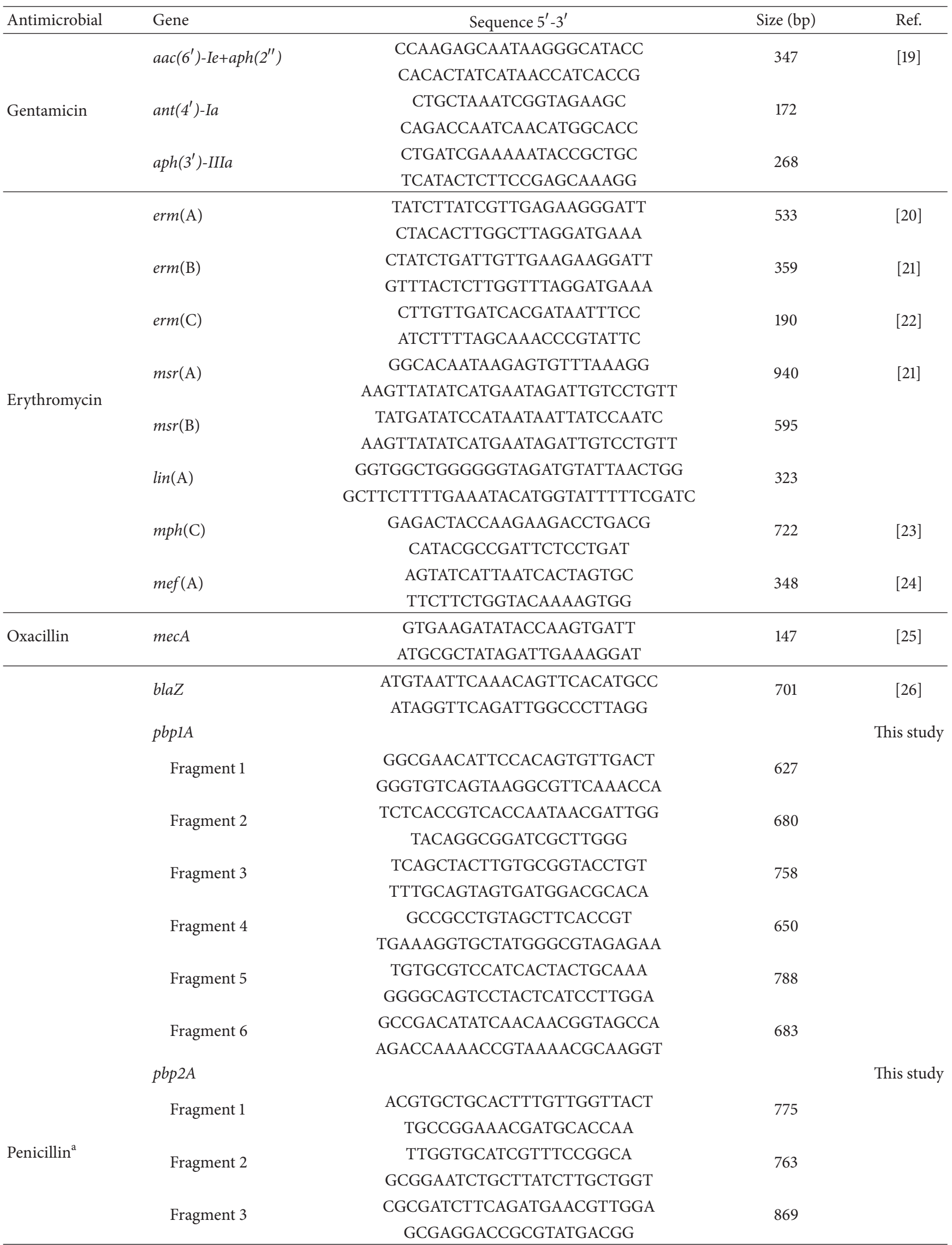


TABle 1: Continued.

\begin{tabular}{|c|c|c|c|c|}
\hline \multirow[t]{19}{*}{ Antimicrobial } & Gene & Sequence $5^{\prime}-3^{\prime}$ & Size (bp) & Ref. \\
\hline & $p b p 3 A$ & & & This study \\
\hline & \multirow{2}{*}{ Fragment 1} & GACGATTATGACGGCCTTTT & \multirow{2}{*}{702} & \\
\hline & & TGGATCAAGTGCAGAACCAG & & \\
\hline & \multirow{2}{*}{ Fragment 2} & CCTGACAGTCAACGAAGCTG & \multirow{2}{*}{769} & \\
\hline & & AAGATCATCGCCACGTGAAC & & \\
\hline & \multirow{2}{*}{ Fragment 3} & GCATTTTCGGTGACGTTTCT & \multirow{2}{*}{714} & \\
\hline & & CGCTCGTAATATCGGTTGGT & & \\
\hline & \multirow{2}{*}{ Fragment 4} & TGATTGATGAGCCGCTTAAA & \multirow{2}{*}{744} & \\
\hline & & ATGGCTCAGGTACTGGTTGG & & \\
\hline & \multirow{2}{*}{ Fragment 5} & GGCATTTAACGAAAAAGATGGA & \multirow{2}{*}{410} & \\
\hline & & TACGTTTACGCGCATGCTAA & & \\
\hline & $p b p 4 A$ & & & This study \\
\hline & \multirow{2}{*}{ Fragment 1} & AATCCAGCGACAAACATCCCATTCA & \multirow{2}{*}{835} & \\
\hline & & AAGCGCAGCAGCATTACTAGAGTT & & \\
\hline & \multirow{2}{*}{ Fragment 2} & GGCGCCATTAATGTTTCGCAAACA & \multirow{2}{*}{718} & \\
\hline & & CGCCGGCGCCCATGATAACT & & \\
\hline & \multirow{2}{*}{ Fragment 3} & GGTGCCGATATGAGCCTAGAAGGT & \multirow{2}{*}{859} & \\
\hline & & TGGGCCATGATTGGGAAGGCG & & \\
\hline \multirow{10}{*}{ Trimethoprim } & \multirow{2}{*}{$d f r D$} & CCСTGCTATTAAAGCACC & \multirow{2}{*}{606} & \multirow{2}{*}{ [27] } \\
\hline & & CATGACCAGATAACTC & & \\
\hline & \multirow{2}{*}{$d f r G$} & TGCTGCGATGGATAAGAA & \multirow{2}{*}{405} & \multirow{6}{*}[26]{} \\
\hline & & TGGGCAAATACCTCATTCC & & \\
\hline & $d f r K$ & CAAGAGATAAGGGGTTCAGC & 229 & \\
\hline & & ACAGATACTTCGTTCCACTC & & \\
\hline & \multirow{2}{*}{$d f r S 1(d f r A)$} & CACTTGTAATGGCACGGAAA & \multirow{2}{*}{270} & \\
\hline & & CGAATGTGTATGGTGGAAAG & & \\
\hline & \multirow{2}{*}{$d f r^{\mathrm{b}}$} & AATGGACATCGGTTGGGTTGCCT & \multirow{2}{*}{484} & \multirow{2}{*}{ This study } \\
\hline & & CGCACCGGATTCAAATGTCTCGC & & \\
\hline \multirow{4}{*}{ Norfloxacin } & gyrA & CGAGTGAGATGCGCGAGTCATTCTT & 731 & This study \\
\hline & & ACGTTGACGACCGCCACCAC & & 1110 stuty \\
\hline & $\operatorname{parC}$ & ACGTTCGTGATGGGCTCAAACCT & 797 & \\
\hline & & ACGTAATCCAGTACGGTCTGTCTCA & & \\
\hline
\end{tabular}

Ref.: reference. ${ }^{\text {a }}$ PCR primers were designed to target smaller $p b p$ 1-4 gene fragments and allow for the respective whole gene sequence amplification;

${ }^{\mathrm{b}}$ chromosomal dihydrofolate reductase.

of mutations in $g y r A$, parC, and $p b p$ ( 1 to 4$)$ and the chromosomal dihydrofolate reductase. The gyrA and parC genes were characterized in the quinolone resistant isolate and four susceptible isolates randomly selected in order to observe specific amino acid substitutions $[35,36]$. For the $p b p$ genes, overlapping primer sequences were designed as to cover smaller fragments, using the S. saprophyticus ATCC 15305 as a template, to allow the determination of the entire gene sequences of the 32 UTI isolates.

2.4. Pulsed-Field Gel Electrophoresis. PFGE was performed with SmaI (20U, New England, Ipswich, USA), as described [37] with the following modifications: (i) bacterial suspensions were prepared in $500 \mu \mathrm{L}$ PIV buffer $[\mathrm{NaCl} 1 \mathrm{M}$ and Tris $\mathrm{HCl} 10 \mathrm{mM}(\mathrm{pH} \mathrm{7,6)]} \mathrm{so} \mathrm{that} \mathrm{an} \mathrm{aliquot} \mathrm{of} \mathrm{the} 1: 10$ diluted suspension in distilled water exhibited an OD of 1.5 in a spectrophotometer with $600 \mathrm{~nm}$ wavelength; (ii) after solidification, blocks were transferred to lysing solution (Tris $\mathrm{HCl} 6 \mathrm{mM}$ [pH 7,6], $\mathrm{NaCl} 1 \mathrm{M}$, EDTA 100 mM [pH 7,5], Brij 58 at $0.5 \%$, sodium lauroyl sarcosinate at $0.5 \%, 0.5 \mathrm{mg} / \mathrm{ml}$ of lysozyme [Sigma], and $0.05 \mathrm{mg} / \mathrm{ml}$ lysostaphin [Sigma]) for $18-24 \mathrm{~h}$ at $37^{\circ} \mathrm{C}$, under gentle agitation. Analysis of band profiles was performed with BioNumerics version 7.1 (Applied Maths, Kortrijk, Belgium) and dendrograms were built with Dice coefficient, 1.0\% tolerance, using UPGMA. Clusters were named with capital letters (A-E) when belonging to the ITU genotypes. Clusters included isolates with $\geq 90 \%$ similarity or with one band difference.

2.5. Data Analysis. Data were analyzed with the free-access program OpenEpi version 3.03 [38]. Differences between categorical variables were analyzed by chi-square or Fisher's 
TABLE 2: Distribution of Staphylococcus saprophyticus isolates obtained from pregnant women's microbiota, beaches, and minas cheese in Rio de Janeiro city.

\begin{tabular}{|c|c|}
\hline Sample source & $\begin{array}{l}\text { Number and \% of } S \text {. } \\
\text { saprophyticus isolates }\end{array}$ \\
\hline \multicolumn{2}{|l|}{ Microbiota (23 positive women) } \\
\hline Vaginal (3) & $\begin{array}{c}11,17 \%(1-5 \text { per } \\
\text { woman) }\end{array}$ \\
\hline Anal (16) & $\begin{array}{c}27,41.5 \%(1-4 \text { per } \\
\text { woman })\end{array}$ \\
\hline Both (4) & $\begin{array}{c}27,41.5 \%(3-9 \text { per } \\
\text { woman) }\end{array}$ \\
\hline Total & 65 \\
\hline \multicolumn{2}{|l|}{ Beach water (10 samples) } \\
\hline Botafogo (2) & $\begin{array}{c}6,20 \%(1-5 \text { per } \\
\text { sample) }\end{array}$ \\
\hline Copacabana (2) & $1,3 \%$ (0-1 per sample) \\
\hline Flamengo (2) & $1,3 \%$ \\
\hline Ipanema (2) & $1,3 \%$ \\
\hline Leblon (2) & $21^{*}, 70 \%$ \\
\hline Total & 30 \\
\hline \multicolumn{2}{|l|}{ Minas cheese (10 cheeses) } \\
\hline Brand A (4) & $\begin{array}{c}9,69.2 \%(0-9 \text { per } \\
\text { cheese })\end{array}$ \\
\hline Brand B (3) & $\begin{array}{c}4,30.7 \%(0-4 \text { per } \\
\text { cheese })\end{array}$ \\
\hline Brand C (3) & 0 \\
\hline Total & $13,100 \%$ \\
\hline Total of S. saprophyticus isolates & 108 \\
\hline
\end{tabular}

${ }^{*}$ The comparison among $S$. saprophyticus obtained from each beach by Fisher's exact test showed that Leblon had significantly higher numbers of isolates than Botafogo, Copacabana, Flamengo, and Ipanema ( $p \leq 0.01)$.

exact test. A $p$ value $\leq 0.05$ was defined as statistically significant.

\section{Results and Discussion}

3.1. Identification of S. saprophyticus from UTI, Pregnant Women's Microbiota, Minas Cheese, and Beach Water. The S. saprophyticus study collection included 32 isolates from UTI [11], 65 isolates from 23 (4\% of 621) pregnant women, 30 isolates from waters of five beaches, and 13 isolates from two minas cheese packs (Table 2).

The finding of $4 \%$ pregnant women colonized with S. saprophyticus was below the colonization occurrence described in the three papers previously published, which reported (i) $11 \%$ of 123 women from a Kidney Clinic [18], (ii) $14 \%$ of 44 UTI cases [39], and (iii) $7 \%$ of 276 women in routine gynecological care [40]. However, our study population is higher (621 women), and the 95\% confidence interval (CI) is the lowest among the others: CI of 0.02-0.05 from our study, (i) CI of 0.009-0.09, (ii) CI of 0.06-0.19, and (iii) CI of $0.03-0.08$. Our finding is robust and suggests a reliable result. The study is refined by genotypic characterization of those isolates and reflects the presence of genes encoding antimicrobial resistance circulating in the human microbiota.

The 30 isolates identified as S. saprophyticus on the five beaches were obtained in both periods: 11 (37\%) in December 2013 and 19 (63\%) in March 2014. In recent years, S. saprophyticus has been described in aquatic environments taken as polluted, such as the marine environment in Lebanon [8] and river flood in Porto Alegre (Brazil) [7]. Here, we observed a high number $(p \leq 0.01)$ of $S$. saprophyticus isolates in Leblon beach, known to receive waters periodically from two fluvial channels carrying untreated domestic sewage. In periods of rain, the channels' floodgates are opened several times to decrease the water level, leading sewage into the sea. There were records of heavy rains during the days prior to sampling, indicating that this practice had recently happened; contamination of seawaters with untreated domestic sewage could explain the high numbers of S. saprophyticus in Leblon. In addition, pregnant women and beach water isolates shared similar resistance gene profiles, indicating a link between these sources.

MALDI-TOF MS confirmed identification of all 140 isolates with scores $>2$ in $84 \%$ and $<2$ in $16 \%$. The scores were consistent with the biochemical tests used to identify $S$. saprophyticus, including values lower than the threshold of 2.0 for species identification $(\geq 1.844)$, as described by others [32]. For coagulase-negatives, in general, this technique is capable of identifying species and subspecies with good performance [41].

The use of selective culture medium was instrumental. Mannitol Salt agar inhibited Gram-negative bacteria, and novobiocin improved the chances to obtain $S$. saprophyticus from cheese and the genital-anal microbiota; moreover, the addition of sodium azide [28] in this medium was essential to isolate $S$. saprophyticus from beach waters. Sodium azide shows bacteriostatic effect to most Gram-negative bacteria; Gram-positive bacteria are usually resistant to this compound [42].

3.2. Antimicrobial Resistance Phenotypes and Genes. Disk diffusion and MIC tests were congruent for susceptibility category. Table 3 shows the analytical findings regarding phenotypic resistance and detection of antimicrobial resistance genes. Comparison of resistance genes present in isolates from the four collections showed a higher concentration of these genes in isolates from pregnant women and beach water (Table 4). This study is the first to report the resistance determinants $d f r A$ and $d f r G$ and $m s r(B)$ and $m p h(C)$ in $S$. saprophyticus obtained from humans.

Trimethoprim-sulfamethoxazole resistance, in 17\% $(n=$ 17) of isolates, correlated with the $d f r G$ or $d f r A$ genes, present in all resistant isolates, and only $10 \%(n=10)$ of susceptible isolates $(p<0.0001)$. The sequence of the chromosomal $d f r$ gene in all isolates was identical to that of trimethoprim susceptible ATCC 15305 strain, and the plasmid genes $d f r G$ and $d f r A$ shared $100 \%$ nucleotide identity with the respective variants described in other staphylococcal species including S. aureus (dfrA: ACSN01000071.1; $d f r G$ : ABFA0100044.1), S. epidermidis (dfrA: NC_002976.3), and S. pseudintermedius (dfrG: NC_014925.1). 
TABLE 3: Antimicrobial susceptibility and resistance determinants in 98 Staphylococcus saprophyticus isolates.

\begin{tabular}{|c|c|c|c|c|}
\hline \multirow[b]{2}{*}{ Antimicrobial agent } & \multirow{2}{*}{$\begin{array}{l}\text { Disk diffusion halo } \\
(\mathrm{mm}) / \text { interpretation }\end{array}$} & \multirow[b]{2}{*}{ MIC $(\mu \mathrm{g} / \mathrm{mL}) /$ interpretation } & \multicolumn{2}{|c|}{ Resistance determinant } \\
\hline & & & Gene & $\begin{array}{c}\text { Number (\%) of } \\
\text { isolates }\end{array}$ \\
\hline \multirow{5}{*}{$\begin{array}{l}\text { Sulfamethoxazole- } \\
\text { trimethoprim }\end{array}$} & $6-12 / \mathrm{R}$ & $4-64 / \mathrm{R}$ & $d f r G$ & $15(15.3)$ \\
\hline & $6 / \mathrm{R}$ & $32 / \mathrm{R}$ & $d f r A$ & $1(1)$ \\
\hline & $11 / \mathrm{I}$ & $8 / \mathrm{R}$ & $d f r G$ & $1(1)$ \\
\hline & $18-35 / \mathrm{S}$ & $0.125-4 / \mathrm{S}$ & $d f r G$ & $10(10.2)$ \\
\hline & $29-37 / S$ & $0.125-2 / \mathrm{S}$ & None & $71(72.4)$ \\
\hline \multicolumn{5}{|l|}{$\mathrm{MLS}_{\mathrm{B}}$} \\
\hline \multirow{14}{*}{ Erythromycin } & $6 / \mathrm{R}$ & $4-\geq 64 / \mathrm{R}$ & $\operatorname{erm}(\mathrm{C})$ & $7(7.1)$ \\
\hline & $6 / \mathrm{R}$ & $32->64 / \mathrm{R}$ & $\operatorname{erm}(\mathrm{C}), m s r(\mathrm{~B})$ & $2(2)$ \\
\hline & $6 / \mathrm{R}$ & $>64 / \mathrm{R}$ & $\operatorname{erm}(\mathrm{C}), m p h(\mathrm{C})$ & $2(2)$ \\
\hline & $6 / \mathrm{R}$ & $\geq 64 / \mathrm{R}$ & $m s r(\mathrm{~A}), m s r(\mathrm{~B})$ & $1(1)$ \\
\hline & $6 / \mathrm{R}$ & $\geq 64 / \mathrm{R}$ & $\operatorname{erm}(\mathrm{C}), m s r(\mathrm{~A}), m s r(\mathrm{~B})$ & $9(9.1)$ \\
\hline & $6-10 / \mathrm{R}$ & $32-\geq 64 / \mathrm{R}$ & $\begin{array}{c}e r m(\mathrm{C}), m s r(\mathrm{~A}), m s r(\mathrm{~B}) \\
m p h(\mathrm{C})\end{array}$ & $10(10.2)$ \\
\hline & 19/I & $0.125 / \mathrm{S}$ & $\operatorname{erm}(\mathrm{C})$ & $1(1)$ \\
\hline & $22-33 / \mathrm{S}$ & $0.125-1 / \mathrm{S}$ & $\operatorname{erm}(\mathrm{C})$ & $44(44.8)$ \\
\hline & $30 / \mathrm{S}$ & $1 / \mathrm{S}$ & $m s r(\mathrm{~A})$ & $1(1)$ \\
\hline & $28-32 / S$ & $0.25-1 / \mathrm{S}$ & $\operatorname{erm}(\mathrm{C}), m s r(\mathrm{~A})$ & $7(7.1)$ \\
\hline & $28-34 / \mathrm{S}$ & $1 / \mathrm{S}$ & $\operatorname{erm}(\mathrm{C}), m s r(\mathrm{~B})$ & $3(3)$ \\
\hline & $27-30 / S$ & $1 / S$ & $\operatorname{erm}(\mathrm{C}), m p h(\mathrm{C})$ & $3(3)$ \\
\hline & $28-30 / \mathrm{S}$ & $1 / \mathrm{S}$ & $\operatorname{erm}(\mathrm{C}), m s r(\mathrm{~A}), m s r(\mathrm{~B})$ & $1(1)$ \\
\hline & $26-32 / \mathrm{S}$ & $0.125-1 / \mathrm{S}$ & None & $7(7.1)$ \\
\hline \multirow{7}{*}{ Clindamycin } & $30-33 / \mathrm{IR}^{\mathrm{a}}$ & $0.125-2 / \mathrm{S}$ & $\operatorname{erm}(\mathrm{C})$ & $6(6.1)$ \\
\hline & $34 / \mathrm{IR}^{\mathrm{a}}$ & $0.25 / \mathrm{S}$ & $\operatorname{erm}(\mathrm{C}), m s r(\mathrm{~B})$ & $1(1)$ \\
\hline & $28-30 / \mathrm{IR}^{\mathrm{a}}$ & $0.25 / \mathrm{S}$ & $\operatorname{erm}(\mathrm{C}), m s r(\mathrm{~A}), m s r(\mathrm{~B})$ & $2(2)$ \\
\hline & $28-32 / \mathrm{IR}^{\mathrm{a}}$ & $0.25 / \mathrm{S}$ & $\begin{array}{c}e r m(\mathrm{C}), m s r(\mathrm{~A}), m s r(\mathrm{~B}) \\
m p h(\mathrm{C})\end{array}$ & $4(4)$ \\
\hline & $25 / \mathrm{S}$ & $0.25 / \mathrm{S}$ & $\begin{array}{c}\operatorname{lin}(\mathrm{A}), \operatorname{erm}(\mathrm{C}), m s r(\mathrm{~A}) \\
m s r(\mathrm{~B}), m p h(\mathrm{C})\end{array}$ & $1(1)$ \\
\hline & $25 / \mathrm{S}$ & $0.25 / \mathrm{S}$ & $\operatorname{lin}(\mathrm{A}), \operatorname{erm}(\mathrm{C})$ & $1(1)$ \\
\hline & $25-35 / \mathrm{S}$ & $0.125-0.25 / \mathrm{S}$ & None & $83(84.6)$ \\
\hline \multirow{5}{*}{ Oxacillin } & $6-9 / \mathrm{R}$ & $32->64 / \mathrm{R}$ & mecA & $3(3)$ \\
\hline & $12 / \mathrm{R}$ & $1 / \mathrm{R}$ & mecA & $1(1)$ \\
\hline & $20-22 / \mathrm{R}$ & $0.5-1 / \mathrm{R}$ & None & $5(5.1)$ \\
\hline & $23-35 / S$ & $0.5-2 / \mathrm{R}$ & None & $84(85.7)$ \\
\hline & $29-44 / \mathrm{S}$ & $0.125-0.25 / \mathrm{S}$ & None & $5(5.1)$ \\
\hline \multirow{6}{*}{ Penicillin } & $6 / \mathrm{R}$ & $8-16 / \mathrm{R}$ & $m e c A^{\mathrm{b}}$ & $3(3)$ \\
\hline & $15 / \mathrm{R}$ & $2 / \mathrm{R}$ & None & $1(1)$ \\
\hline & $26-28 / \mathrm{R}$ & $0.25-1 / \mathrm{R}$ & None & $2(2)$ \\
\hline & $22 / \mathrm{R}$ & $0.125 / \mathrm{S}$ & $m e c A^{\mathrm{b}}$ & $1(1)$ \\
\hline & $17-27 / \mathrm{R}$ & $0.125 / \mathrm{S}$ & None & $9(9.1)$ \\
\hline & $30-45 / \mathrm{S}$ & $\leq 0.125 / \mathrm{S}$ & None & $82(83.6)$ \\
\hline \multirow{3}{*}{ Gentamicin } & $14 / \mathrm{I}$ & $8 / \mathrm{I}$ & None & $1(1)$ \\
\hline & $15 / S$ & $8 / \mathrm{I}$ & None & $1(1)$ \\
\hline & $15-37 / S$ & $0.125 / \mathrm{S}$ & None & 96 (97.9) \\
\hline \multirow{2}{*}{ Norfloxacin } & $15 / \mathrm{I}$ & $0.125 / \mathrm{S}$ & None & $1(1)$ \\
\hline & $17-33 / S$ & $0.125 / \mathrm{S}$ & None & 97 (98.9) \\
\hline
\end{tabular}

The 98 isolates in this table were selected from the 140 obtained to include only one isolate per patient. $\mathrm{MLS}_{\mathrm{B}}$ : macrolide-lincosamide-streptogramin $\mathrm{B}$; R: resistant; I: intermediate resistance; S: susceptible; IR: inducible resistance; MIC: minimum inhibitory concentration. ${ }^{a}$ All inducible resistance detected in $D$ test. ${ }^{\mathrm{b}}$ Same isolates resistant to oxacillin. 
TABLE 4: Distribution of the antimicrobial resistance genes by sample source among the 98 Staphylococcus saprophyticus isolates.

\begin{tabular}{|c|c|c|c|c|c|}
\hline \multirow[b]{2}{*}{ Gene } & \multicolumn{5}{|c|}{ Number and $\%$ in each collection } \\
\hline & $\begin{array}{c}\mathrm{UTI} / 2005-2006 \\
\quad N=32\end{array}$ & $\begin{array}{c}\text { Pregnant } \\
\text { women/2011-2013 } \\
N=23\end{array}$ & $\begin{array}{c}\text { Beach } \\
\text { water/2013-2014 } \\
N=30\end{array}$ & $\begin{array}{c}\text { Cheese/2011 } \\
N=13\end{array}$ & $\begin{array}{c}\text { Total } \\
N=98\end{array}$ \\
\hline \multicolumn{6}{|l|}{$\mathrm{MLS}_{\mathrm{B}}$} \\
\hline ermC & $24(75)$ & $6(26)$ & $10(33.3)$ & $11(84.6)$ & $78(79.5)$ \\
\hline$m s r A$ & $0(0)$ & $0(0)$ & $1(3.3)$ & 0 & $34(34.6)$ \\
\hline$m s r B$ & $0(0)$ & $0(0)$ & $0(0)$ & 0 & $26(26.5)$ \\
\hline$m p h C$ & $0(0)$ & $0(0)$ & $0(0)$ & 0 & $18(18.3)$ \\
\hline erm $C, m s r A$ & 0 & $4(17.3)$ & $3(10)$ & 0 & $7(7.1)$ \\
\hline erm $C, m s r B$ & 0 & $2(8.6)$ & $1(3.3)$ & 0 & $3(3)$ \\
\hline $\operatorname{erm} C, \operatorname{lin} A$ & 0 & 0 & $1(3.3)$ & 0 & $1(1)$ \\
\hline erm $C, m p h C$ & 0 & $2(8.6)$ & $3(10)$ & 0 & $5(5.1)$ \\
\hline$m s r A, m s r B$ & 0 & 0 & $1(3.3)$ & 0 & $1(1)$ \\
\hline erm $C, m s r A, m s r B$ & $5(16)$ & $2(8.6)$ & $3(10)$ & 0 & $10(10.2)$ \\
\hline erm $C, m s r A, m p h C$ & 0 & $2(8.6)$ & 0 & 0 & $2(2)$ \\
\hline erm $C, m s r A, m s r B, m p h C$ & 0 & $4(17.3)$ & $5(16.6)$ & 0 & $10(10.2)$ \\
\hline erm $C, m s r A, m s r B, m p h C, \operatorname{lin} A$ & 0 & 0 & $1(3.3)$ & 0 & $1(1)$ \\
\hline$>1$ gene $^{\mathrm{a}}$ & $5(15.6)$ & $16(69.5)$ & $20(20.4)$ & 0 & $41(41.8)$ \\
\hline \multicolumn{6}{|l|}{ Other } \\
\hline$d f r G$ & $16(50)$ & $7(30.4)$ & $3(10)$ & 0 & $26(26.5)$ \\
\hline$d f r A$ & $1(3.1)$ & $0(0)$ & $0(0)$ & 0 & $1(1)$ \\
\hline mecA & $0(0)$ & $2(8.6)$ & $2(6.6)$ & 0 & $4(4)$ \\
\hline
\end{tabular}

$\mathrm{MLS}_{\mathrm{B}}$ : macrolide-lincosamide-streptogramin B. ${ }^{\mathrm{a}} p<0.001$ for comparison of $>1$ gene present among isolates from UTI or cheese and pregnant women and from UTI or cheese and beach water.

Although $\mathrm{MLS}_{\mathrm{B}}$ antimicrobial agents are not recommended for UTI treatment [43], several genes that encode resistance to these agents were reported in S. saprophyticus. The most frequently described in this species is $\operatorname{erm}(\mathrm{C})$ $[13,14,23,44]$, almost universally present among our UTI isolates $(n=29 / 91 \%$; Table 4$)$. MLS ${ }_{\mathrm{B}}$ resistance genes were present in resistant and susceptible isolates alike (Table 3). The $\operatorname{erm}(\mathrm{C})$ gene shared $100 \%$ nucleotide identity with those described in S. aureus (NC_007792.1) and S. haemolyticus (NC_007170.1). Both $m s r(\mathrm{~A})$ and $m s r(\mathrm{~B})$ genes shared $99 \%$ of nucleotide identity with $S$. aureus (CP002141.1) and $S$. xylosus (M81802.1), respectively. The $m p h(\mathrm{C})$ gene had $99 \%$ identity with those described in S. aureus (CP007177.1) and S. epidermidis (GQ900458.1).

In the more recent collections, a combination of genes replaced the $\operatorname{erm}(\mathrm{C})$ gene as a sole $\mathrm{MLS}_{\mathrm{B}}$ resistance determinant, a difference certainly due to the time lag between strains' isolation periods (2005-2006 for UTI and 2011-2013 for other isolates) (Table 4). Concerning clindamycin resistance, only inducible phenotype was observed in $13 \%$ of isolates $(n=13)$. Resistant isolates had different combinations of $\operatorname{erm}(\mathrm{C}), m s r(\mathrm{~A}), m s r(\mathrm{~B}), m p h(\mathrm{C})$, and $\operatorname{lin}(\mathrm{A})$. The $\operatorname{lin}(\mathrm{A})$ gene shared $100 \%$ and $99 \%$ identity with the genes already described in S. aureus (EU350088.1) and S. haemolyticus (M14039.1), respectively.

$\beta$-Lactam resistance was rarely supported by molecular mechanism (Table 3). Oxacillin resistance was confirmed in only four isolates (4\%) with the mecA gene, though $9 \%$ of isolates were resistant by disk diffusion and $93 \%$ by MIC determination. We observed 89 non-mec $A$ isolates with oxacillin-resistant breakpoints, though with low MIC values $(0.5 \mu \mathrm{g} / \mathrm{mL}-2 \mu \mathrm{g} / \mathrm{mL})$. It has been suggested that the most appropriate breakpoints to cefoxitin disk diffusion and oxacillin MIC should be $\leq 19 \mathrm{~mm}$ and $\geq 16 \mu \mathrm{g} / \mathrm{mL}$, respectively, to indicate mecA-positive $S$. saprophyticus [45]. With these criteria, all 89 S. saprophyticus isolates would be classified as susceptible. However, this MIC breakpoint [45] would be inappropriate for one of the mecA-positive isolates from beach waters, with MIC $1 \mu \mathrm{g} / \mathrm{ml}$, confirmed in triplicate. On the other hand, the suggested cefoxitin inhibition zone $<19 \mathrm{~mm}$ would fit, since this $m e c A$-positive isolate had a $12 \mathrm{~mm}$ halo.

Penicillin resistance by MIC correlated with the presence of mecA gene in only three isolates (Table 3). Other three penicillin-resistant isolates ( $\mathrm{MIC} \leq 1 \mu \mathrm{g} / \mathrm{mL}$ ) had no resistance determinant, including blaZ or PBP nucleotide sequence polymorphisms that distinguished resistant from susceptible isolates. By comparing PBP sequences of the 32 UTI isolates with those of $S$. saprophyticus ATCC 15305, we found only substitutions unrelated to phenotypic penicillin resistance in the PBP1 deduced amino acid sequence: V625M in 31 isolates and E731K in all 32 isolates. The contribution of the two substitutions in the deduced amino acid sequence of PBP1 to antimicrobial resistance is yet to be unraveled. 


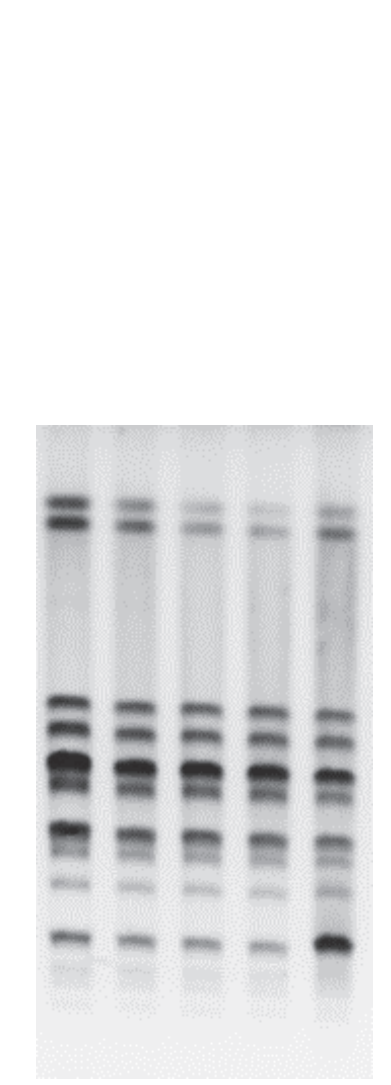

(a)
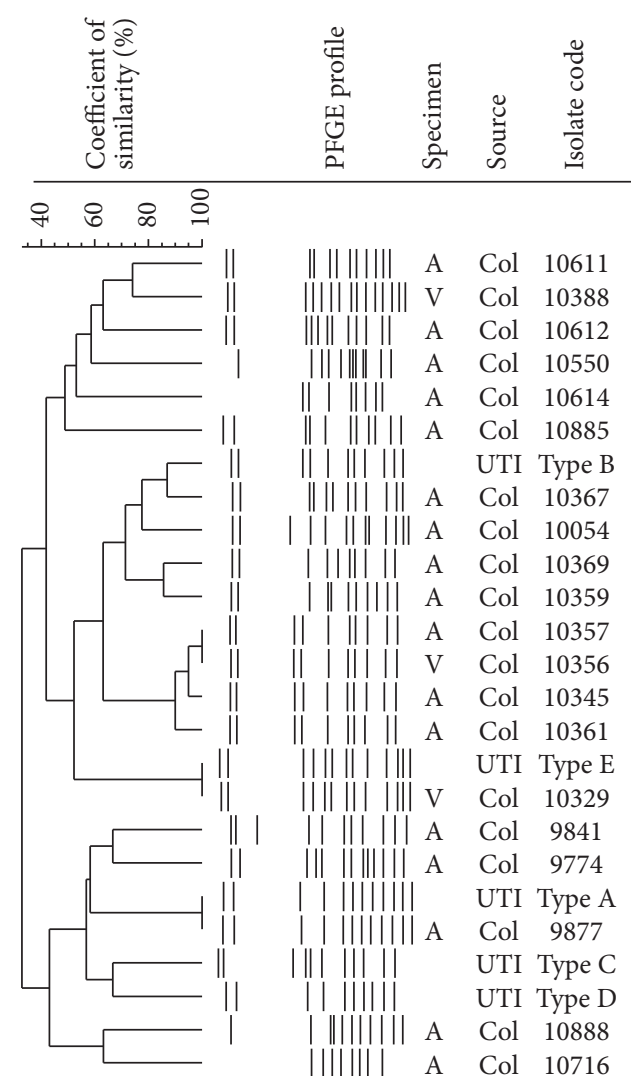

|||||||||||| V Col 10388

||| ||| A A Col 10612

|||||||| A Col 10550

|| ||| A A Col 10614

|| || || || A A Col 10885

| | || || UTI Type B

| || || ||| A Col 10367

| || || || ||| A Col 10054

| |||| || A Col 10369

| || ||||| A Col 10359

|| || || A Col 10357

|| | ||||| $\mathrm{V}$ Col 10356

|| ||||| A A Col 10345

|| ||| || A A Col 10361

||| || ||| UTI Type E

|| || || |||| V Col 10329

|| || ||| A Col 9841

||| || ||||| A Col 9774

| ||l|||l UTI Type A

| ||l||l| A Col 9877

| || ||| || UTI Type C

|| |||l| UTI Type D

| |||||||| A Col 10888

|l||l|| A Col 10716

(b)

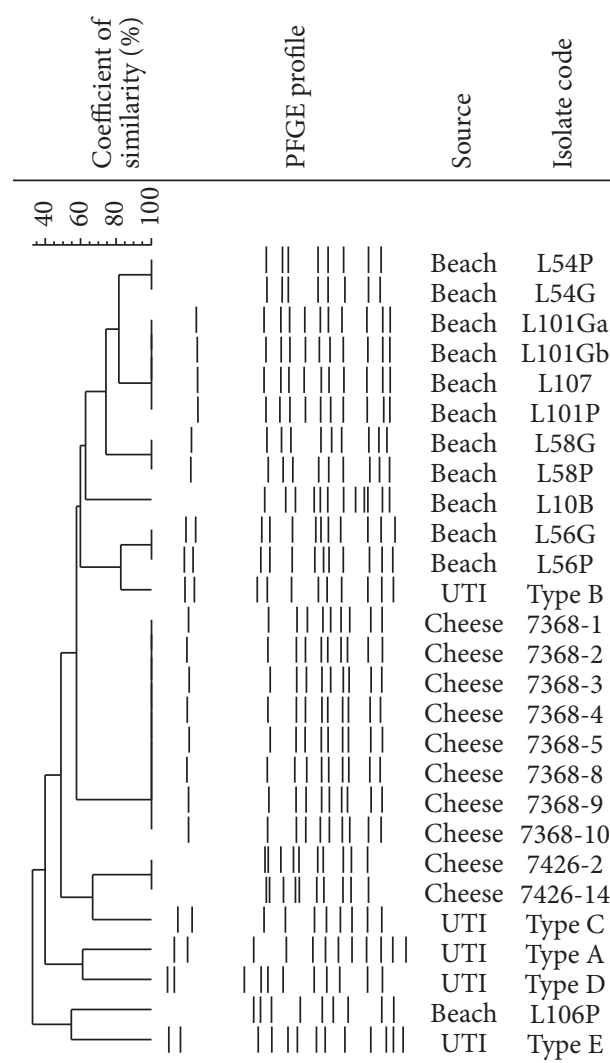

(c)

FIGURE 2: Pulsed-field gel electrophoresis profiles of the Staphylococcus saprophyticus isolates obtained from pregnant women, minas cheese, and beach waters of Rio de Janeiro. PFGE band patterns of (a) five isolates obtained from the microbiota of a single pregnant women; (b) comparison of the five uropathogenic PFGE clusters with one isolate per pregnant woman $(n=21)$ and (c) 10 isolates from minas cheese and 12 from beach waters. "A": anal; "V": vaginal.

Two of the mecA-positive isolates were obtained from the microbiota of pregnant women (Table 4). The presence of this isolate may indicate risk of UTI by oxacillin-resistant S. saprophyticus to this group. Although S. saprophyticus is uncommon UTI agent in pregnant women [46], treatment of such infections in this population is performed with first-generation cephalosporins, such as cephalexin [47], a $\beta$-lactam without activity for $m e c A$-carrying isolates. In addition, colonized pregnant women may represent a risk for transmission of resistant microorganisms to the newborn [48], as already shown to occur with resistant enterobacteria $[49,50]$.

Regarding other drugs, even though one isolate was intermediately resistant to norfloxacin, no gyrA and parC gene mutations were found (Table 3). It is possible that the result of the disk diffusion test was false-positive, since the MIC was susceptible and the corresponding mutations were not found with the resistance phenotype. In the case of the two isolates with intermediate resistance to gentamicin (Table 3), it was not possible to elucidate mechanisms of resistance through the aminoglycoside-modifying enzymeencoding genes studied. This suggests that additional mechanisms of resistance may be involved in the expression of this phenotype for this microorganism.
3.3. PFGE Typing. We performed typing to investigate if multiple isolates from colonization in microbiota would be clonal and to compare our isolates from the multiple sources with the five PFGE clusters we detected previously.

From the total 23 pregnant women with $S$. saprophyticus, isolates from 21 were typeable. This collection included 43 isolates from 10 women with more than one isolate and one from each of 11 women with a single isolate (54 isolates in total). PFGE band profiles from a single individual were mostly clonal: six women had profiles $90 \%-100 \%$ similar (Figure 2(a)), and the other four were colonized with isolates $76 \%-100 \%$ similar (three band differences at most). Our strategy to type more than one colony per women to study the microbiota may be helpful for future epidemiological studies, as we demonstrated that $S$. saprophyticus isolates from the same person are usually clonal.

Comparison of PFGE profiles from different women (Figure 2(b)) showed that four of them shared profiles $>90 \%$ similar, and comparison with the previously detected clones revealed that each of two women had isolates $100 \%$ similar with UTI type A and others with UTI type E. This result indicates that $S$. saprophyticus clones can stay successfully established in the environment and among people; UTI and pregnant women's microbiota PFGE types 
were obtained almost a decade apart. Similar results were previously observed in Germany but only among UTI isolates [51].

Of the 10 typeable isolates from cheese, only those from the same cheese pack were clonal (100\% similar, Figure 2(c)). Our results indicate single original contamination in the cheese sample, but this may not be the rule, as another study in France showed polyclonal contamination in this same food [3]. It is possible that a large number of cheese packs from more brands would show a different clonal composition per cheese as the study in France. More studies regarding this issue are needed to support this food as a possible source of UTI. Despite the difference between the UTI and the cheese types in the present study, this food could be a brief point source of $S$. saprophyticus to humans.

We obtained 12 typeable isolates from beach water (all from Leblon beach). Only isolates from the same culture plate were clonal (100\% similar, Figure 2(c)). Although we did not observe clusters with $>90 \%$ similarity among beach waters and UTI isolates, one S. saprophyticus from beach and another from UTI (type B pattern) had similarity of $82 \%$ (two band differences). Further studies are needed to investigate a possible connection among beach water and human UTI isolates. Indeed, the association between ITU by $S$. saprophyticus and swimming activities was described long ago [52]. However, only a technique such as whole genome sequencing could propose the transmission direction of strains from food to humans.

PFGE performance was unsuccessful for $18 \mathrm{~S}$. saprophyticus isolates from beach waters. The reason for such failure may relate to bacterial survival strategy in saturated environment such as beach waters. Possible changes in $S$. saprophyticus cell wall could differentiate isolates in beach waters. Such differences were demonstrated in marine Pseudomonas aeruginosa [53]. Indeed, PFGE protocols are validated for clinical isolates and may be less suitable for environmental organisms.

Comparison among PFGE profiles of all isolates showed that the similarity detected in smaller groups of isolates remained (data not shown).

\section{Conclusions}

The presence of similar genotypic characteristics (high presence of resistance genes) in isolates from microbiota and beach waters indicates that $S$. saprophyticus may transit between both sites. Likewise, the two isolates with mecA gene and full resistance to oxacillin in beach waters alert to the possibility of transmission of this highly relevant resistance determinant to other humans. On the other hand, the finding of $S$. saprophyticus fully susceptible to antimicrobial agents in minas cheese suggests that these isolates represent microorganisms in their wild state in the environment.

Resistance to oxacillin and gentamicin was little related to genes screened in this study. Additional investigations are needed to assess the discrepancies observed here. The unconfirmed resistance to norfloxacin by MIC or mutations in QRDR regions indicated that the disk diffusion test was inaccurate.
The PFGE association of isolates from microbiota with $100 \%$ similarity, compared to two PFGE UTI cluster types obtained one decade apart, shows long-term persistence of uropathogenic types.

\section{Conflicts of Interest}

The authors declare that there are no conflicts of interest regarding the publication of this paper.

\section{Acknowledgments}

The authors thank Ana Maria Nunes Botelho, Maria Cícera Carvalho, and Agnes Marie de Sá Figueiredo for the genotypic screening of the cefoxitin-resistant isolates. This research was supported by Conselho Nacional de Desenvolvimento Científico e Tecnológico (CNPq), Coordenação de Aperfeiçoamento de Pessoal de Nível Superior (CAPES), Fundação de Amparo à Pesquisa do Estado do Rio de Janeiro (FAPERJ) of Brazil, and the Fogarty International Program in Global Infectious Diseases (TW006563) of the National Institutes of Health.

\section{References}

[1] A. Eriksson, C. G. Giske, and A. Ternhag, "The relative importance of Staphylococcus saprophyticus as a urinary tract pathogen: distribution of bacteria among urinary samples analysed during 1 year at a major Swedish laboratory," Acta Pathologica, Microbiologica, et Immunologica Scandinavica, vol. 121, no. 1, pp. 72-78, 2013.

[2] J. C. Soares, M. R. Marques, F. K. Tavaria, J. O. Pereira, F. X. Malcata, and M. M. Pintado, "Biodiversity and characterization of Staphylococcus species isolated from a small manufacturing dairy plant in Portugal," International Journal of Food Microbiology, vol. 146, no. 2, pp. 123-129, 2011.

[3] E. Coton, M.-H. Desmonts, S. Leroy et al., "Biodiversity of coagulase-negative Staphylococci in french cheeses, dry fermented sausages, processing environments and clinical samples," International Journal of Food Microbiology, vol. 137, no. 23, pp. 221-229, 2010.

[4] A. M. M. Abd-Elall, M. E. M. Mohamed, and M. A. I. Awadallah, "Potential airborne microbial hazards for workers on dairy and beef cattle farms in Egypt," Veterinaria Italiana, vol. 45, no. 2, pp. 275-285, 2009.

[5] S. Leroy, P. Giammarinaro, J.-P. Chacornac, I. Lebert, and R. Talon, "Biodiversity of indigenous staphylococci of naturally fermented dry sausages and manufacturing environments of small-scale processing units," Food Microbiology, vol. 27, no. 2, pp. 294-301, 2010.

[6] V. L. M. Rall, J. M. Sforcin, M. F. R. de Deus et al., "Polymerase chain reaction detection of enterotoxins genes in coagulasenegative staphylococci isolated from Brazilian minas cheese," Foodborne Pathogens and Disease, vol. 7, no. 9, pp. 1121-1123, 2010.

[7] A. P. Basso, P. D. Martins, G. Nachtigall, S. van der Sand, T. M. de Moura, and A. P. G. Frazzon, "Antibiotic resistance and enterotoxin genes in Staphylococcus sp. Isolates from polluted water in southern Brazil," Anais da Academia Brasileira de Ciencias, vol. 86, no. 4, pp. 1813-1820, 2014. 
[8] S. Harakeh, H. Yassine, S. Hajjar, and M. El-Fadel, "Isolates of Staphylococcus aureus and saprophyticus resistant to antimicrobials isolated from the Lebanese aquatic environment," Marine Pollution Bulletin, vol. 52, no. 8, pp. 912-919, 2006.

[9] D. Sergelidis, A. Abrahim, T. Papadopoulos et al., "Isolation of methicillin-resistant Staphylococcus spp. from ready-to-eat fish products," Letters in Applied Microbiology, vol. 59, no. 5, pp. 500-506, 2014.

[10] B.-S. Kim, C.-T. Kim, B. H. Park et al., "Draft genome sequence of Staphylococcus saprophyticus subsp. saprophyticus M1-1, isolated from the gills of a Korean rockfish, sebastes schlegeli hilgendorf, after high hydrostatic pressure processing," Journal of Bacteriology, vol. 194, no. 16, pp. 4441-4442, 2012.

[11] V. S. de Sousa, R. F. Rabello, R. C. D. S. Dias et al., "Time-based distribution of Staphylococcus saprophyticus pulsed field gelelectrophoresis clusters in community-acquired urinary tract infections," Memorias do Instituto Oswaldo Cruz, vol. 108, no. 1, pp. 73-76, 2013.

[12] M. Sousa, N. Silva, G. Igrejas et al., "Antimicrobial resistance determinants in Staphylococcus spp. recovered from birds of prey in Portugal," Veterinary Microbiology, vol. 171, no. 3-4, pp. 436-440, 2014.

[13] M. A. Fernández-Fuentes, H. Abriouel, E. Ortega Morente, R. Pérez Pulido, and A. Gálvez, "Genetic determinants of antimicrobial resistance in Gram positive bacteria from organic foods," International Journal of Food Microbiology, vol. 172, pp. 49-56, 2014.

[14] A. Le Bouter, R. Leclercq, and V. Cattoir, "Molecular basis of resistance to macrolides, lincosamides and streptogramins in Staphylococcus saprophyticus clinical isolates," International Journal of Antimicrobial Agents, vol. 37, no. 2, pp. 118-123, 2011.

[15] O. C. Sampimon, T. J. G. M. Lam, D. J. Mevius, Y. H. Schukken, and R. N. Zadoks, "Antimicrobial susceptibility of coagulasenegative staphylococci isolated from bovine milk samples," Veterinary Microbiology, vol. 150, no. 1-2, pp. 173-179, 2011.

[16] B. Söderquist and C. Berglund, "Methicillin-resistant Staphylococcus saprophyticus in Sweden carries various types of staphylococcal cassette chromosome mec (SCCmec)," Clinical Microbiology and Infection, vol. 15, no. 12, pp. 1176-1178, 2009.

[17] D. T. Dubin, J. E. Fitzgibbon, M. D. Nahvi, and J. F. John, "Topoisomerase sequences of coagulase-negative staphylococcal isolates resistant to ciprofloxacin or trovafloxacin," Antimicrobial Agents and Chemotherapy, vol. 43, no. 7, pp. 1631-1637, 1999.

[18] P. A. Jordan, A. Iravani, G. A. Richard, and H. Baer, "Urinary tract infection caused by Staphylococcus saprophyticus," Journal of Infectious Diseases, vol. 142, no. 4, pp. 510-515, 1980.

[19] F.-J. Schmitz, A. C. Fluit, M. Gondolf et al., "The prevalence of aminoglycoside resistance and corresponding resistance genes in clinical isolates of staphylococci from 19 European hospitals," Journal of Antimicrobial Chemotherapy, vol. 43, no. 2, pp. 253259, 1999.

[20] M. C. P. Nguyen, P.-L. Woerther, M. Bouvet, A. Andremont, R. Leclercq, and A. Canu, "Escherichia coli as reservoir for macrolide resistance genes," Emerging Infectious Diseases, vol. 15, no. 10, pp. 1648-1650, 2009.

[21] G. Lina, A. Quaglia, M.-E. Reverdy, R. Leclercq, F. Vandenesch, and J. Etienne, "Distribution of genes encoding resistance to macrolides, lincosamides, and streptogramins among staphylococci," Antimicrobial Agents and Chemotherapy, vol. 43, no. 5, pp. 1062-1066, 1999.

[22] F. Martineau, F. J. Picard, N. Lansac et al., "Correlation between the resistance genotype determined by multiplex PCR assays and the antibiotic susceptibility patterns of Staphylococcus aureus and Staphylococcus epidermidis," Antimicrobial Agents and Chemotherapy, vol. 44, no. 2, pp. 231-238, 2000.

[23] P. Lüthje and S. Schwarz, "Antimicrobial resistance of coagulase-negative staphylococci from bovine subclinical mastitis with particular reference to macrolide-lincosamide resistance phenotypes and genotypes," Journal of Antimicrobial Chemotherapy, vol. 57, no. 5, pp. 966-969, 2006.

[24] M. Santagati, F. Iannelli, M. R. Oggioni, S. Stefani, and G. Pozzi, "Characterization of a genetic element carrying the macrolide efflux gene mef(A) in Streptococcus pneumoniae," Antimicrobial Agents and Chemotherapy, vol. 44, no. 9, pp. 2585-2587, 2000.

[25] K. Zhang, J.-A. McClure, S. Elsayed, T. Louie, and J. M. Conly, "Novel multiplex PCR assay for characterization and concomitant subtyping of staphylococcal cassette chromosome mec types I to V in methicillin-resistant Staphylococcus aureus," Journal of Clinical Microbiology, vol. 43, no. 10, pp. 5026-5033, 2005.

[26] M. A. Argudin, B. A. Tenhagen, A. Fetsch et al., "Virulence and resistance determinants of german Staphylococcus aureus ST398 isolates from nonhuman sources," Applied and Environmental Microbiology, vol. 77, no. 9, pp. 3052-3060, 2011.

[27] G. E. Dale, H. Langen, M. G. P. Page, R. L. Then, and D. Stuber, "Cloning and characterization of a novel, plasmidencoded trimethoprim- resistant dihydrofolate reductase from Staphylococcus haemolyticus MUR313," Antimicrobial Agents and Chemotherapy, vol. 39, no. 9, pp. 1920-1924, 1995.

[28] S. R. Stengren and M. J. Starzyk, "A modified medium for the recovery of Staphylococcus from water," Microbios, vol. 41, no. 165-166, pp. 191-203, 1984.

[29] Y. Salfinger and M. L. Tortorello, Compendium of Methods for the Microbiological Examination of Foods, American Public Health Association, Washington, DC, USA, 2001.

[30] L. F. Montezzi, E. H. Campana, L. L. Corrêa et al., "Occurrence of carbapenemase-producing bacteria in coastal recreational waters," International Journal of Antimicrobial Agents, vol. 45, no. 2, pp. 174-177, 2015.

[31] T. L. Bannerman and S. J. Peacock, "Staphylococcus Micrococcus, and other catalase- positive cocci," in Manual of Clinical Microbiology, P. R. Murray, E. L. Baron, J. H. Jorgensen, M. L. Landry, and M. A. Pfaller, Eds., pp. 390-401, Washington, DC, USA, 2007.

[32] T.-F. Lee, H. Lee, C.-M. Chen et al., "Comparison of the accuracy of matrix-assisted laser desorption ionization-time of flight mass spectrometry with that of other commercial identification systems for identifying Saphylococcus saprophyticus in urine," Journal of Clinical Microbiology, vol. 51, no. 5, pp. 1563-1566, 2013.

[33] CLSI, Methods for Dilution Antimicrobial Susceptibility Tests for Bacteria That Grow Aerobically: Approved Standard, Clinical and Laboratory Standards Institute, Pa, USA, 9th, (M07-A9) edition, 2012.

[34] CLSI., Performance Standards for Antimicrobial Susceptibility Testing; Twenty-Fifth Informational Supplement, Clinical and Laboratory Standards Institute, Pa, USA, 2015.

[35] M. Yamada, J. Yoshida, S. Hatou, T. Yoshida, and Y. Minagawa, "Mutations in the quinolone resistance determining region in Staphylococcus epidermidis recovered from conjunctiva and their association with susceptibility to various fluoroquinolones," British Journal of Ophthalmology, vol. 92, no. 6, pp. 848851, 2008. 
[36] L. J. V. Piddock, "Mechanisms of fluoroquinolone resistance: an update 1994-1998," Drugs, vol. 58, no. 2, pp. 11-18, 1999.

[37] R. F. Rabello, C. R. V. M. Souza, R. S. Duarte, R. M. M. Lopes, L. M. Teixeira, and A. C. D. Castro, "Characterization of Staphylococcus aureus isolates recovered from bovine mastitis in Rio de Janeiro, Brazil," Journal of Dairy Science, vol. 88, no. 9, pp. 3211-3219, 2005.

[38] K. M. Sullivan, A. Dean, and M. M. Soe, "OpenEpi: a web-based epidemiologic and statistical calculator for public health," Public Health Reports, vol. 124, no. 3, pp. 471-474, 2009.

[39] P. Hedman, O. Ringertz, K. Olsson, and R. Wollin, "Plasmididentified Staphylococcus saprophyticus isolated from the rectum of patients with urinary tract infections," Scandinavian Journal of Infectious Diseases, vol. 23, no. 5, pp. 569-572, 1991.

[40] M. E. Rupp, D. E. Soper, and G. L. Archer, "Colonization of the female genital tract with Staphylococcus saprophyticus," Journal of Clinical Microbiology, vol. 30, no. 11, pp. 2975-2979, 1992.

[41] T. Spanu, E. De Carolis, B. Fiori et al., "Evaluation of matrixassisted laser desorption ionization-time-of-flight mass spectrometry in comparison to $r p o B$ gene sequencing for species identification of bloodstream infection staphylococcal isolates," Clinical Microbiology and Infection, vol. 17, no. 1, pp. 44-49, 2011.

[42] H. C. Lichstein and M. H. Soule, "Studies of the effect of sodium azide on microbic growth and respiration," Journal of Bacteriology, vol. 47, no. 3, pp. 221-230, 1944.

[43] K. Gupta et al., "International clinical practice guidelines for the treatment of acute uncomplicated cystitis and pyelonephritis in women: a 2010 update by the infectious diseases society of america and the european society for microbiology and infectious diseases," Clinical Infectious Diseases, vol. 52, no. 5, pp. e103-e120, 2011.

[44] C. Strauss, Y. Hu, A. Coates, and V. Perreten, "A novel erm(44) gene variant from a human Staphylococcus saprophyticus confers resistance to macrolides, lincosamides but not streptogramins," Antimicrobial Agents and Chemotherapy, vol. 61, no. 1, Article ID e01655-16, 2016.

[45] M. Higashide, M. Kuroda, S. Ohkawa, and T. Ohta, "Evaluation of a cefoxitin disk diffusion test for the detection of mecA-positive methicillin-resistant Staphylococcus saprophyticus," International Journal of Antimicrobial Agents, vol. 27, no. 6, pp. 500-504, 2006.

[46] J. Matuszkiewicz-Rowińska, J. Małyszko, and M. Wieliczko, "Urinary tract infections in pregnancy: old and new unresolved diagnostic and therapeutic problems," Archives of Medical Science, vol. 11, no. 1, pp. 67-77, 2015.

[47] M. Lee, P. Bozzo, A. Einarson, and G. Koren, "Urinary tract infections in pregnancy," Canadian Family Physician, vol. 54, no. 6, pp. 853-854, 2008.

[48] F. Chereau, P. Herindrainy, B. Garin et al., "ESBL- and NDM1-producing Enterobacteriaceae colonization among pregnant women in the community in a low income country: a potential reservoir for transmission of multi-resistant Enterobacteriaceae to neonates," Antimicrobial Agents and Chemotherapy, vol. 59, no. 6, pp. 3652-3655, 2015.

[49] L. A. Denkel, F. Schwab, A. Kola et al., "The mother as most important risk factor for colonization of very low birth weight (VLBW) infants with extended-spectrum $\beta$-lactamaseproducing Enterobacteriaceae (ESBL-E)," Journal of Antimicrobial Chemotherapy, vol. 69, no. 8, Article ID dku097, pp. 22302237, 2014.

[50] A. Pathak, S. P. Chandran, K. Mahadik, R. Macaden, and C. S. Lundborg, "Frequency and factors associated with carriage of multi-drug resistant commensal Escherichia coli among women attending antenatal clinics in Central India," BMC Infectious Diseases, vol. 13, no. 1, article 199, 2013.

[51] M. Widerström, J. Wiström, S. Ferry, C. Karlsson, and T. Monsen, "Molecular epidemiology of Staphylococcus saprophyticus isolated from women with uncomplicated community-acquired urinary tract infection," Journal of Clinical Microbiology, vol. 45, no. 5, pp. 1561-1564, 2007.

[52] P. Hedman and O. Ringertz, "Urinary tract infections caused by Staphylococcus saprophyticus. a matched case control study," Journal of Infection, vol. 23, no. 2, pp. 145-153, 1991.

[53] N. H. Khan, M. Ahsan, W. D. Taylor, and K. Kogure, "Culturability and survival of marine, freshwater and clinical Pseudomonas aeruginosa," Microbes and Environments, vol. 25, no. 4, pp. 266$274,2010$. 

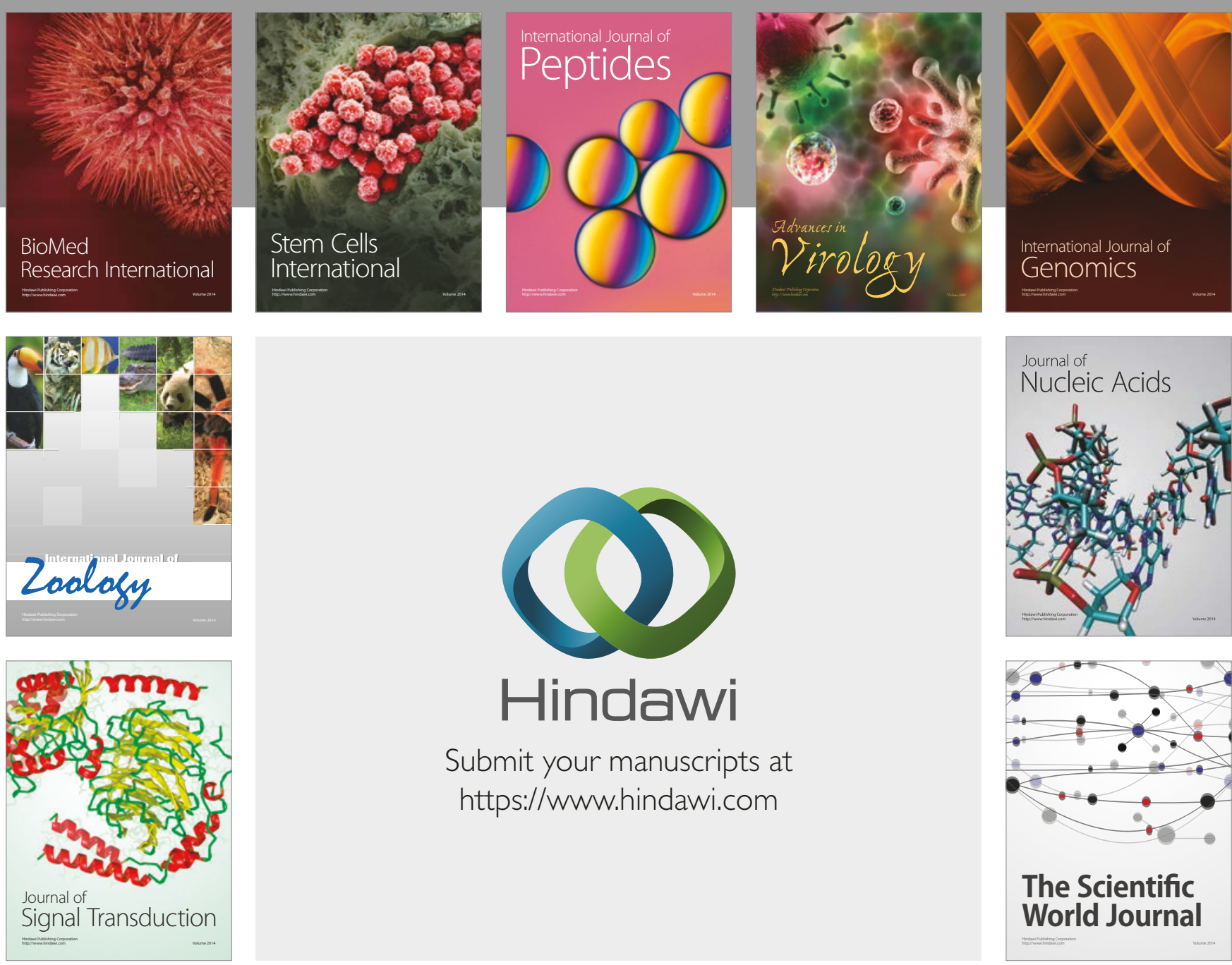

Submit your manuscripts at

https://www.hindawi.com
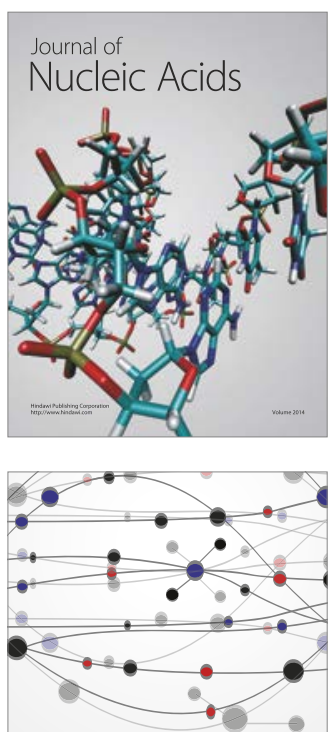

The Scientific World Journal

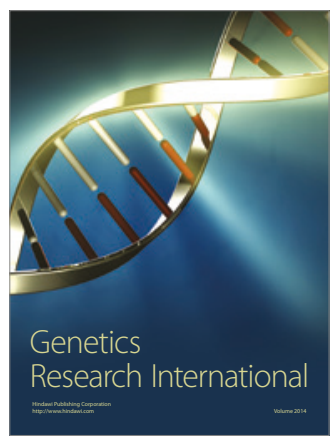

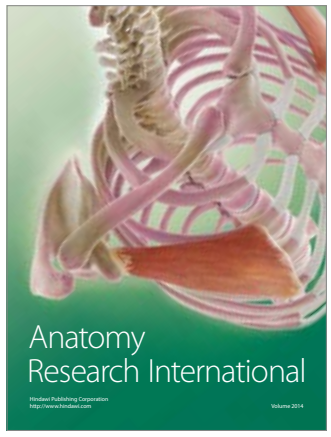

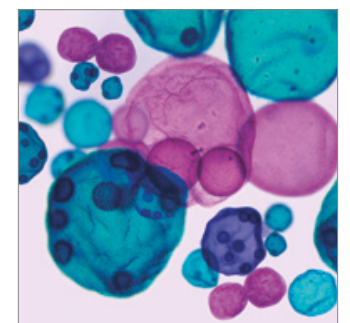

International Journal of Microbiology
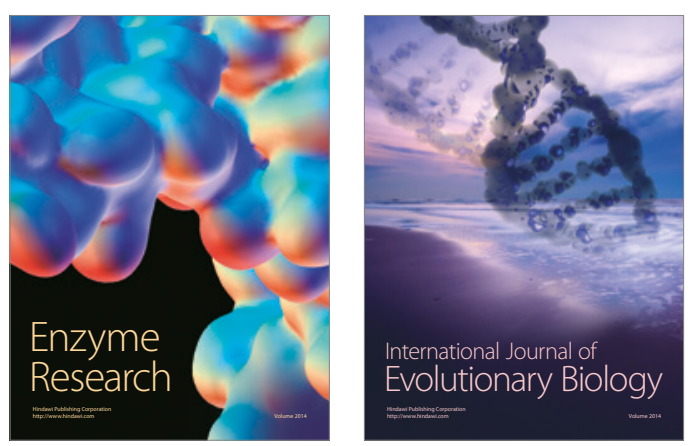
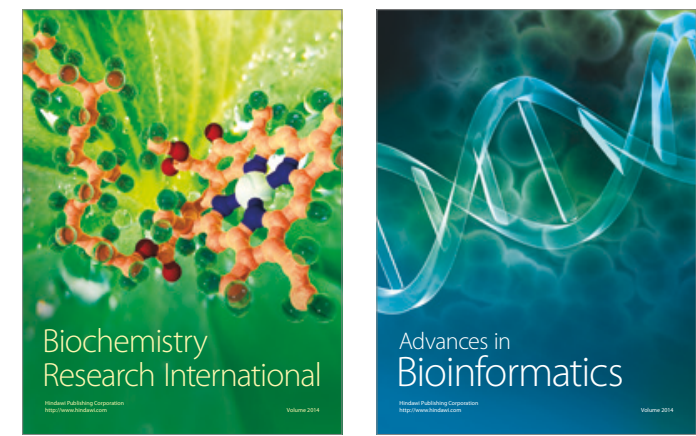

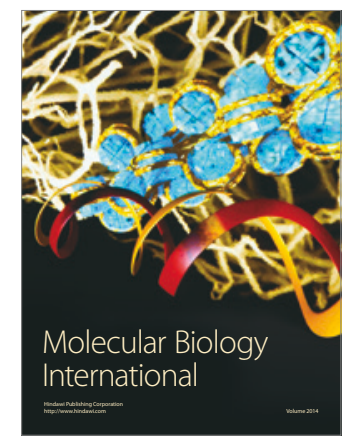

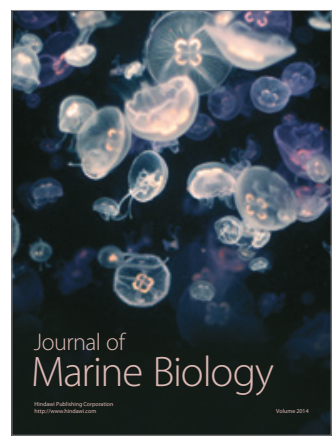

